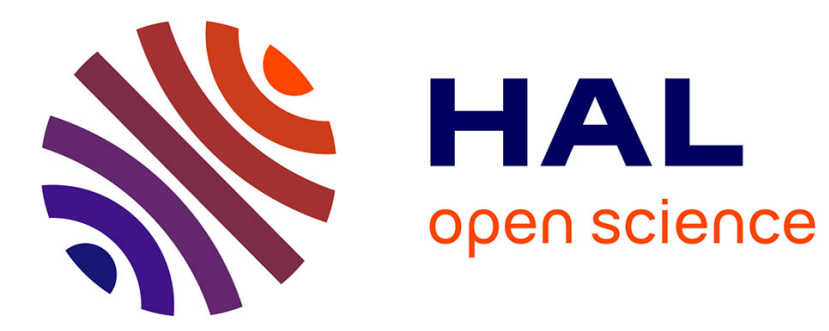

\title{
Early interventions for youths at high risk for bipolar disorder: a developmental approach
}

\author{
Xavier Benarous, Angèle Consoli, Vanessa Milhiet, David Cohen
}

\section{To cite this version:}

Xavier Benarous, Angèle Consoli, Vanessa Milhiet, David Cohen. Early interventions for youths at high risk for bipolar disorder: a developmental approach. European Child and Adolescent Psychiatry, 2016, 25 (3), pp.217-233. 10.1007/s00787-015-0773-6 . hal-01303787

\section{HAL Id: hal-01303787 https://hal.sorbonne-universite.fr/hal-01303787}

Submitted on 18 Apr 2016

HAL is a multi-disciplinary open access archive for the deposit and dissemination of scientific research documents, whether they are published or not. The documents may come from teaching and research institutions in France or abroad, or from public or private research centers.
L'archive ouverte pluridisciplinaire HAL, est destinée au dépôt et à la diffusion de documents scientifiques de niveau recherche, publiés ou non, émanant des établissements d'enseignement et de recherche français ou étrangers, des laboratoires publics ou privés. 


\title{
Early interventions for youths at high risk for bipolar disorder: A developmental approach
}

\author{
Xavier Benarous ${ }^{1}$, Angèle Consoli ${ }^{12}$, Vanessa Milhiet $^{1}$, David Cohen $^{13}$ \\ ${ }^{1}$ Service de Psychiatrie de 1'Enfant et de 1'Adolescent, Hôpital Pitié-Salpêtrière, 47-83 \\ Boulevard de l'Hôpital, 75013 Paris, France \\ 2 INSERM U-669, PSIGIAM, Paris, France \\ ${ }^{3}$ CNRS UMR 7222, Institut des Systèmes Intelligents et Robotiques
}

Address of correspondence: Xavier Benarous, Service de Psychiatrie de l'Enfant et de l'Adolescent, Université Pierre et Marie Curie, Hôpital Pitié-Salpêtrière, AP-HP, 47-83, Boulevard de l'Hôpital, 75013, Paris, France

Email: $\underline{\text { xavierbenarous@gmail.com }}$

Telephone: $+33(0) 603260193$

Fax number: $+33(0) 142162331$

Abbreviated title: Early interventions for bipolar disorder

Conflict of interest: On behalf of all authors, the corresponding author states that there is no conflict of interest. 


\title{
Early interventions for youths at high risk for bipolar disorder: A developmental approach
}

\begin{abstract}
In recent decades, ongoing research programs on primary prevention and early identification of bipolar disorder (BD) have been developed. The aim of this article is to review the principal forms of evidence that support preventive interventions for $\mathrm{BD}$ in children and adolescents and the main challenges associated with these programs. We performed a literature review of the main computerised databases (MEDLINE, PUBMED) and a manual search of the literature relevant to prospective and retrospective studies of prodromal symptoms, premorbid stages, risk factors, and early intervention programs for BD. Genetic and environmental risk factors of BD were identified. Most of the algorithms used to measure the risk of developing BD and the early interventions programs focused on the familial risk. The prodromal signs varied greatly and were age-dependent. During adolescence, depressive episodes associated with genetic or environmental risk factors predicted the onset of hypomanic/manic episodes over subsequent years. In prepubertal children, the lack of specificity of clinical markers and difficulties in mood assessment were seen as impeding preventive interventions at these ages. Despite encouraging results, biomarkers have not thus far been sufficiently validated in youth samples to serve as screening tools for prevention. Additional longitudinal studies in youths at high risk of developing BD should include repeated measures of putative biomarkers. Staging models have been developed as an integrative approach to specify the individual level of risk based on clinical (e.g., prodromal symptoms and familial history of BD) and non-clinical (e.g., biomarkers and neuroimaging) data. However, there is still a lack of empirically validated studies that measure the benefits of using these models to design preventive intervention programs.
\end{abstract}


Keywords: Early onset bipolar disorder; high-risk study; prevention; early intervention; children; staging models

\section{Introduction}

Over the past few decades, preventive interventions have been proposed to prevent or limit the consequences of bipolar disorder (BD) in adults. Because more than half of adult patients with $\mathrm{BD}$ present their first episode before the age of 18 [1,2], these programs would mainly concern children and adolescents. This concern is of particular importance with regard to the high level of functional impairment in affected children and adolescents. BD is the fourth leading cause of disability among youths aged 10-24 worldwide and is associated with an increased risk of suicide [3,4]. In this paper, the evidence that supports the development of such interventions at these ages is discussed. First, to understand the growing interest in the development of a preventive approach, the natural course of BD is discussed. Second, we examine whether the following criteria for the development of an effective prevention of BD in paediatric samples have been met: (i) genetic and environmental risk factors for BD must be identified in view of defining a target population; (ii) clinical markers that predict the onset and/or the course of the disease must be determined; (iii) endophenotypes or biomarkers that reflect an early pathological process could help to identify individuals who require special attention, and (iv) the effectiveness of preventive interventions must be evaluated. Finally, the use of staging models that were previously developed for psychosis, has been proposed for BD. These models were conceived as tools based on clinical (e.g., symptoms and family history of BD) and non-clinical (e.g., neuroimaging and biological markers) parameters for measuring the risk of progression over the course of the disease. It is 
seen as a rational approach to adapting treatments with potential side-effects to a specific situation according to the individual level of risk. However, despite a theoretical framework that supports the use of staging models in $\mathrm{BD}$, few studies have examined the empirical evidence. This review will examine the internal and external validity of models that focus on the transition from a non-symptomatic at-risk status to the first manic episode.

\section{The life-time course of bipolar disorder}

Although BD has traditionally been described as a cyclical disorder with euthymic periods, in recent decades, the clinical importance of inter-episode symptoms has been highlighted. It has been noted that symptom-free periods are actually rare in bipolar patients, who continue to report subsyndromal affective symptoms between episodes [5]. An aggravation of the disease with more severe symptoms and shorter periods between relapse is observed throughout the course of BD in a sizeable proportion of patients [6-9]. The concepts of kindling and neuro sensitisation were coined to describe the phenomenon of a progressive increase in episode frequencies as the mood episodes repeated [8,9]. Although this concept have largely been cited in support of the promotion of early interventions in $\mathrm{BD}$, this assumption has been contradicted by empirical evidences [10,11]. In a 30 year follow-up study among outpatients with BD (N=220), Angst and Selloro found that a shortening of cycle length only occurred in the first few, but not in later episodes [10]. In addition to subthreshold symptoms, some degree of cognitive impairment also persists during euthymic periods in patients with BD [12-14]. Increasing cognitive difficulties have been reported over the course of the disorder and are correlated with the number of manic episodes [15]. Longitudinal studies in adults have supported the assumption that inter-episode functioning 
decreases as the disease progresses in most individuals with BD $[16,17,6]$. This progressive course is seen as a key factor in explaining the poorer functional outcomes in BD patients with delayed treatment compared with others $[1,2,18]$. Indeed, patients with a prolonged phase of untreated illness report on average a lower rate of employment [19], a higher number of hospitalisations [20], more forensic complications, and a higher level of functional impairment [3,21]. The view of $\mathrm{BD}$ as both a progressive and cyclical disease is also supported by different responses to treatment observed according to the stages of the illness $[6,9,18]$. The number of manic episodes that a patient experiences has been associated with greater resistance to pharmacological treatment $[8,9,22]$. However, these findings were not replicated when the response to lithium was examined in a large 20 -year follow-up study among adults with BD [23]. Concerning psychological interventions, cognitive behavioural therapy (CBT) and psychoeducational therapy have shown more effectiveness in the early stages of the disease compared with the later stages [24-26]. However, a meta-analysis found that the number of previous thymic episodes had no impact on psychotherapeutic effectiveness [27]. These conflicting results could stem from the heterogeneity of BD in terms of the illness course and treatment response [28,29]. Preventive interventions would aim to reverse or slow the life-time course of $\mathrm{BD}$, in particular in those who present severe disease progression. In the next section, the criteria that are required for the development of such programs for BD in children and adolescents will be examined.

2. Criteria for the development of effective preventive interventions in the paediatric population

(i) Genetic and environmental risk factors 
If a preventive strategy is to be developed, genetic and non-genetic risk factors must be determined to identify sub-groups that are at high risk of BD transition. Table 1 presents the main risk factors that have been identified for the onset and progression of BD.

\section{$\underline{\text { Genetic factors }}$}

A positive family history of $\mathrm{BD}$ is the strongest independent risk factor for the development of related mood disorders [30,31]. Twin and family studies have reported a $59-87 \%$ heritability of $\mathrm{BD}$, and the concordance rates between identical twins range from 40 to $97 \%$ [32]. Based on the DSM-IV criteria for BD-I and BD-II, first-degree relatives have a $23 \%$ chance of developing a mood disorder; within this $23 \%$, the chance of developing a form of BD is approximately 9\% [30]. Considering the high heritability rate, the offspring of BD parents appear to be good candidates for determining the efficacy of early intervention strategies. However, it should be mentioned that such an approach would omit subjects who do not have first-degree relatives with BD.

\section{$\underline{\text { Environmental factors }}$}

In addition to genetic predisposition, some environmental risk factors could impact the lifetime course of BD. Approximately $50 \%$ of $\mathrm{BD}$ patients have histories of severe trauma or abuse during childhood [33]. In retrospective studies and prospective outpatient studies, early sexual abuse has been associated with an earlier age of BD onset, a greater frequency of comorbidities, increased symptom severity and suicidal ideation, an increased number of mood episodes, and greater treatment resistance [33-35]. For example, Geller et al. found that 
low ratings of maternal warmth and greater parent-child conflict are associated with earlier recurrences over four years among childhood and preadolescent bipolar patients [33]. The poorer course of bipolar youths who were exposed to childhood abuse/neglect has also been supported by epidemiological studies. Data from the National Comorbidity Survey Replication indicated that a history of maltreatment predicted earlier onset and longer episode duration of BP [34]. The dose-effect relationship observed between childhood maltreatment and the severity of BD suggests that adverse life events have an effect across the different stages of the disease [35]. It has been suggested that early adversity mediates the relationship between genetic vulnerability and an early onset of the illness, which in turn predicts a less favourable prognosis [33]. Two general comments are worth mentioning with regard to these findings. On one hand, the association between abuse/neglect and the onset of BD was not investigated in the prospective high-risk studies conducted in the offspring of parents with BD. Thus, regarding maltreatment as a strong prognosis factor does not imply that it should be considered as an independent risk factor for the onset of BD. Moreover the fact that high conversion rates to $\mathrm{BD}$ were observed in pediatric sample associated with a low prevalence of abuse and neglect indicates that stressful life events are neither necessary nor sufficient to develop BD $[35,36]$. The association between $\mathrm{BD}$ and maltreatment found in cross-sectional studies of the offspring of parents with BD could partly reflect general difficulties in the parenting practices of adults with $\mathrm{BD}$ [36]. On the other hand, it is important to determine whether the results found in outpatient studies were an artefact of the inclusion of youths with dysregulated mood who were misdiagnosed as having BD (such as youths with Disruptive Mood Dysregulation Disorder).

Substance use also impacts the course of BD. Approximately, $60 \%$ of individuals with BD will develop substance abuse or dependence [37]. Conversely, substance abuse was reported 
to be a risk factor for developing $\mathrm{BD}$ in retrospective studies and in prospective studies among the offspring of parents with BD [38,39].

Long-term treatment with antidepressant medications precipitates or exacerbates manic symptoms and reduces the age of onset of mania [40]. A potential risk for episodes of mania induced by stimulant medications was supported by preliminary evidence; but not confirmed by more recent prospective studies $[41,42]$.

[Insert Table 1 about here]

\section{$\underline{\text { Limitations and further research }}$}

Beyond the recognition of environmental and genetic risk factors for BD in children and adolescents, there is still much to be done to understand the interactions between these factors. Some of the identified factors could be inter-correlated (e.g., substance abuse and maltreatment), some factors could be necessary for the development of others, and some factors could simply co-occur. A better understanding of the common pathophysiological pathways that mediate the effect of different risk factors could help to develop effective interventions. For example, Meyer et al. found that the effect of maternal negativity on the early onset of $\mathrm{BD}$ among the offspring of mothers with $\mathrm{BD}$ was mainly mediated by difficulties in executive cognitive abilities [43]. Finally, the moderating effects of protective factors, such as temperament and social and familial environment, should be better understood. 


\section{(ii) Specific clinical symptoms during the prodromal stages}

Before detailing prodromal symptoms, several points about methodologic issues are worth noting. Different types of studies have been conducted to determine which symptoms precede the onset of BD. Retrospective studies are surveys in which adult participants describe the symptoms that precede the onset of BD [1,44-46,2]. These retrospective studies have supported the view that a prodromal phase exists in BD during childhood [1,2]. However, methodological biases (such as a recall bias or a lack of precision in estimating the age of onset) make modelling the course of the prodromal symptoms difficult. In contrast, prospective studies provide reliable and detailed data on the course of bipolar prodromal symptoms because clinical symptoms are estimated through repeated assessments of youths prior to the onset of BD. Recent reviews have detailed the prodromal symptoms of BD $[47,18]$. In this article, we present only the main results from those prospective studies.

\section{$\underline{\text { Studies of child and adolescent outpatients }}$}

Follow-up studies that monitored the rates of diagnostic conversion to BD among outpatient youths with behavioural/emotional problems have been conducted. Typically, subjects are included when their symptoms are severe enough for them or their families to seek admission for assessment and treatment. Consequently, these studies are prone to Berkson bias and a high comorbidity rate is usually reported. The Course and Outcome of Bipolar Youth (COBY) study is a large US prospective outpatient study that included youths with manic symptoms who did not meet the criteria for a diagnosis of maniac/mixed episode (i.e., bipolar disorder not otherwise specified, BD-NOS). The COBY team found that $25 \%$ of 92 children 
and adolescents with BD-NOS had converted to BD-I or BD-II at a 2-year follow-up [48]. At a 4-year follow-up, $38 \%$ of 141 BD-NOS subjects had converted to BD-I or BD-II.

Geller et al. examined the transition to BD among young adults who had participated in a study of pharmacological treatment for childhood depression. At a 10 -year follow-up, $49 \%$ of 72 subjects with prepubertal major depression had converted to some form of BD [49].

Kochman et al. conducted a 2-year follow-up study in children and adolescents with a major depressive disorder and probands with bipolar disorder. They found that those who presented a combination of elevated mood with irritability and rapid mood fluctuations (labelled cyclotaxia) were more likely to develop a manic episode [50].

Akiskal et al. found that "mood lability", "energy-activity" and "daydreaming" trait factors strongly predicted conversion to BD-II in youths with unipolar depression [51].

\section{$\underline{\text { Studies in a community-based sample }}$}

Longitudinal studies conducted in an unselected community-based sample can facilitate the generalisation of findings. In the Dunedin (New-Zealand) birth cohort ( $\mathrm{N}=922$ children), Kim-Cohen et al. found that $74 \%$ of the adults with BD presented early signs before 18 and $50 \%$ before 15 years. All of the adults who developed BD had already presented a paediatric psychiatric disorder: anxiety disorder, and/or depressive disorder, and/or disruptive disorder [52]. In The Great Smoky Mountains Study (N=717 children), youths who developed BD were more likely to present a psychiatric disorder in adolescence, such as anxiety $(\mathrm{OR}=20)$, depressive disorder $(\mathrm{OR}=5.4)$, disruptive disorder $(\mathrm{OR}=6.3)$ and personality disorder $(\mathrm{OR}=6.8)[53,54]$. In a 15-year follow-up Swedish community-based study $(\mathrm{N}=2,300)$, Paaren et al. reported that among adolescents with a major depressive disorder, those with early disruptive disorders or multiple somatic symptoms in childhood were more likely to 
develop BD in adulthood (respectively, $\mathrm{OR}=3.6$ and $\mathrm{OR}=6.6$ ) [55]. In this study, of the 64 adolescents with hypomania spectrum episodes during childhood, only 6 developed a hypomanic/manic episode as adults. Anxiety disorders (panic attack and general anxiety disorder) substantially increase this risk $(\mathrm{OR}=12.0)$ [55].

\section{$\underline{\text { Studies of offspring of parents with BD }}$}

As developed earlier, heritability is the most robust risk factor for BD. Therefore, providing data about bipolar prodrome by studying the offspring of probands with $\mathrm{BD}$ is a major strategy. In addition to the cost of these studies, the main limitation concerns the generalisation of the findings to youths who do not have a family history of BD.

Akiskal et al. conducted a 3-year follow-up study on youths who were admitted for services and whose parents presented BD. Those who developed BD were more likely to present anxiety, minor mood symptoms and adjustment disorders before the onset of BD [56]. The first mood disturbances were depressive in polarity and occurred before adolescence, whereas mixed and psychotic episodes occurred after puberty.

Hillegers et al. studied the risk of developing BD in a sample of 129 high-risk Dutch adolescents [35]. After 5 years of follow-up, 12 out of the 13 adolescents who developed BD had first presented a depressive episode at adolescence. On average, a hypomanic episode appears 4.9 years after the first depressive episode.

Shaw et al. compared 110 at-risk children who had a BD-I parent to children who had healthy parents in the Amish population. They found a higher frequency of broad spectrum episodic symptoms in offspring of bipolar parents: anxiety, inattention at school, easily excited behaviour, hyper alertness, mood lability, and somatic complaints [57]. A further 5-year follow-up led to determining five additional symptoms in adolescents: variations in sleep and 
energy, problems with thinking/concentration, excessive talking, and loud talking [58]. Egeland et al. suggested that the prodromal symptoms of BD would encompass episodic signs before 6 years old (such as crying, anxiety, over sensitivity, somatic complaints) and more adult-like symptoms from 7 to 12 (such as anxiety and variation in sleep and energy, emotional lability, shyness, functional impairment) [58].

Duffy et al. assessed the diagnostic status and conversions to BD after a 4-year follow-up of 127 high-risk offspring [36]. The lifetime prevalence of BD increased from $6 \%$ to $20 \%$ compared to the offspring from control families. Of 40 offspring with sleep and/or anxiety disorders, 12 developed $\mathrm{BD}$, and 12 developed depressive disorders. The index mood episode in those who developed BD was almost always depression. A history of anxiety was found to increase the risk for the development of any mood disorder from $40 \%$ to $85 \%$, approximately 8 years after the beginning of the anxiety symptoms [40]. Similarly, sleep disturbances that preceded BD occurred several years before the onset of the first mood episode. The same team hypothesised that a majority of offspring of bipolar adults who went on to develop BD observed a typical chronological sequence of prodromal symptoms. Among the 207 offspring, approximately $71 \%$ of the children who developed BD followed this sequence: non-mood symptoms (i.e., sleep disturbances and anxiety disorder) first appear in the prepubertal child; then, non-specific minor mood symptoms emerge around puberty; the onset of recurrent major depressive episodes occurs later in mid-adolescence; and finally, the first hypomanic/manic episode occurs years later [39].

Axelson et al. examined the risk of developing BD in 391 high-risk offspring aged 6-18 years. After a 6.8-year follow-up, subthreshold manic or hypomanic episodes $(\mathrm{OR}=2.3)$, major depressive episodes ( $\mathrm{OR}=2.0)$, and disruptive behaviour disorders $(\mathrm{OR}=2.1)$ were associated with a higher risk of developing BD [59]. 


\section{Limitations and further research}

Based on previous findings, a model has been proposed (Figure 1) to illustrate the course of prodromal symptoms over time in children and adolescents before the onset of BD in young adults. This model highlights the increasing specificity of the prodromal symptoms observed over time and their different predictive values, depending on the stage of development. Two different periods should be distinguished. In prepubertal at-risk children, non-mood (e.g., anxiety) and minor mood (e.g., sleep disturbance) symptoms were associated with a higher transition to BD. Identifying the possible candidates for bipolar preventive intervention based on these symptoms raised two difficulties. First, on a practical level, concerns have been raised regarding the difficulties of distinguishing minor mood symptoms from mood variations within the normal range in the youngest children [60,61]. Second, it is still unclear to what extent these symptoms predict $\mathrm{BD}$, or any other psychiatric disorder (e.g., unipolar depression or psychosis). As suggested by Kim-Cohen et al., bipolar prodromal symptoms are difficult to distinguish from symptoms that precede unipolar depression or psychosis [52]. In addition, the inclusion of paediatric subthreshold manic-like symptoms into the adult bipolar spectrum raised a great deal of controversy [60]. With respect to this issue, the substantial amount of literature that was devoted to the so-called paediatric presentation of BD clarified some issues. Evidence supports that episodic and persistent mood symptoms should be distinguished because only the former predicts BD [62-64]. For example, Stringaris et al. noted that among 84 youths with non-episodic irritability, only one developed hypomanic/manic or mixed episodes over a 2-year follow-up [62]. Similarly, a large amount of longitudinal data supports that persistent and chronic mood symptoms predict unipolar depression and anxiety, but not BD, in adults. Such distinctions have been endorsed by the 
recent inclusion of Disruptive Mood Dysregulation in the chapter of depressive disorders in the DSM-5 classificatory systems.

In adolescents, high-risk studies showed that in most cases, affective disturbances begin during adolescence and are depressive in polarity [36,35,57]. Few manic or mixed episodes were reported before puberty, while more than $90 \%$ of BD patients presented depressive symptoms in mid-adolescence $[65,35]$. Certain characteristics of the depressive episode were associated with an increased risk of developing BD: an acute onset [66], a weight gain, somatic preoccupations, a diminished concentration, a predominantly irritable mood [67], psychotic features, severe psychomotor retardation (e.g., Cotard syndrome) [68], and medication-induced hypomanic symptoms [69].

[Insert Figure I about here]

Research on at-risk children for BD highlight two fundamental principles of developmental psychopathology: equifinality and multifinality. Equifinality means that multiple developmental pathways can converge on the same clinical outcome [70]. A large amount of evidence in adults supports that different subtypes of BD with distinct risk factors and clinical courses exist. Such heterogeneity could represent additional difficulty in determining a unique pattern of bipolar prodromal symptoms for all presentations $[29,28]$. The notion of multifinality reflects the variety of trajectories that could arise from one specific constellation of prodromal symptoms. On the one hand, the lack of specificity of prodromal bipolar symptoms makes the identification of a clear at-risk group based on clinical approach difficult, especially because subthreshold manic and depressive symptoms are much more common in the general population than those for psychosis. On the other hand, a large 
overlap between prodromal symptoms for psychosis and for BD have been observed [71]. At this time, preventive programs should focus on the identification of depressive episodes in youths who present with genetic and/or environmental risk factors. Such programs must be considered as a secondary prevention because these symptoms reflect the initial thymic episode as illustrated in Figure I.

\section{(iii) Endophenotypes and biomarkers}

Considering the limited specificity of symptoms that are described during the prodromal stages, non-clinical indicators could prove to be valuable in distinguishing youths who are at high risk of developing BD from others. An endophenotype is a heritable biological trait that serves as a marker of risk for a later disorder [72]. Endophenotypes could help to identify individuals who are likely to manifest prodromal states of BD. Biomarkers have been proposed to reflect dysfunctional neurobiological mechanisms that facilitate the onset and progression of BD [73]. Moreover, the identification of such markers could help to define possible targets for preventive approaches.

\section{$\underline{\text { Temperamental traits }}$}

Studies have examined whether specific temperamental traits can confer additional risk of developing $\mathrm{BD}$ in vulnerable individuals [74,75,50,76-78]. Most of these studies have compared temperamental features between offsprings of unaffected parents, offspring of bipolar parents with and without psychopathology [75,74,77]. For example, emotionality (defined as an easy tendency to cry and react intensively when upset) was positively 
associated with the risk of having a mood disorder in a cohort of offsprings of parents with BD [75]. Doucette et al. [78] examining temperament profiles among offspring of a parent with $\mathrm{BD}(\mathrm{N}=221)$ found that those who exhibited a high level of emotionality were more likely to develop a mood disorder $(\mathrm{OR}=1.24)$ compared to offspring from families with unaffected parent.

A cyclothymic temperament (i.e., with highly mood-lability and emotionally overactive) was found to be a predictor of switching to BD in a population of children and adolescents with major depressive disorder $(\mathrm{N}=80)$ in a 2-year follow-up study [50]. Evans et al. [76] confirmed that cyclothymic temperamental traits are present at a higher rate within BD adults than in unaffected relatives of patients with $\mathrm{BD}$, and then in controls.

As noted by Duffy et al. [75], further longitudinal studies of temperament features that predispose to $\mathrm{BD}$ could help to a better understanding of the interplay between genetic factors, psychopathology and undesirable life events in youth who later develop BD. Further studies are also needed to determine how these temperament traits cosegregate with BD within families and if it is specific to BD [74].

\section{Endocrine and inflammatory markers}

Preliminary studies in this field have explored the role of cortisol and the increased activity in the hypothalamic-pituitary-adrenal (HPA) axis in mood disorders [79]. Subtle abnormalities in the HPA system were found to predict the development of affective disorder. For example, high-risk offspring of parents with $\mathrm{BD}$ tend to exhibit higher levels of cortisol during the afternoon compared to low-risk offspring [79]. However, further studies are needed to understand whether cortisol can be considered a marker of vulnerability to $\mathrm{BD}$, an 
etiopathological factor, or the biological response to chronic stress in youths who present non-specific emotional/behavioural symptoms. A major focus was placed on markers of neuroinflammation, neurotrophic factors and oxidative stress, considering their putative roles in the pathophysiology of $\mathrm{BD}[6,73,80,14,81,82]$. An increase in the level of peripheral proinflammatory markers (such as TNF- $\alpha$ and interleukine-6) and a decrease in the level of circulating brain-derived neurotrophic factor (BDNF) were reported initially during thymic episodes and then during euthymic periods [83-85]. Despite the keen interest in the development of inflammatory markers for $\mathrm{BD}$, caution is required because the main assumptions were extrapolated from studies that were conducted in adults with existing BD. For example, none of the studies of biomarkers in $\mathrm{BD}$ that were reviewed in a recent metaanalysis included subjects who were below the age of 18 years [73]. Only two studies have been conducted with paediatric samples. Padmos et al. found that monocyte activation of inflammatory genes predicted the development of mood disorders in adolescent bipolar offspring $(n=54)$ [86]. Mesman et al. conducted a prospective study to examine the evolution of inflammatory biomarkers in 140 children of parents with BD. They found an increased expression of genes that are involved in the inflammatory process during adolescence (e.g., cytokines pentraxin 3), and a decrease in the expression of BDNF [87].

\section{$\underline{\text { Neurocognitive impairment }}$}

When it exists, the neurocognitive impairment that is found in BD usually appears at a late stage of the disease. For example, unlike psychosis disorders, such deficits were not systematically reported after the first acute episode [88]. However, minor deficits in executive function, verbal memory, and attention have been described in unaffected children who are at risk of developing the disease [88-91,43]. Deficits in the labelling of facial 
emotional expression have been found in unaffected relatives compared to healthy control subjects [89]. Schenkel et al. found that bipolar youths had more difficulty performing social cognitive tasks that measure theory of mind (i.e., inferences of others' thoughts or intentions) compared with controls, especially in emotional contexts [90]. Whitney et al. noted significant impairments in social reciprocity in youths who have a parent with BD and presented mood dysregulation symptoms without BD. However, in this study, no difference in performance with regard to theory of mind or affect recognition was found [91]. A smaller study on the offspring of BD parents reported an association between the results on the Wisconsin Card Sorting Test and a later risk for the development of BD [43].

\section{$\underline{\text { Neuroanatomical features }}$}

Cortical atrophy, an enlargement of the ventricles and a reduction in the grey matter volume, were noted over the course of BD [14,92-94]. However, compared to psychosis disorders, fewer structural impairments were found at an early and very early stage (e.g., prior to the onset of the first thymic episode) [93]. A progressive loss of brain grey matter in the frontal lobe was reported in a 2-year follow-up period after the first psychotic episode relative to controls [95]. Emerging data from longitudinal neuroimaging studies are beginning to elucidate abnormalities in cortical development associated with a higher risk of developing BD. For example, a reduction in the level of $\mathrm{N}$-acetylaspartate, a marker of neuronal integrity, was found in the dorsolateral prefrontal cortices and hippocampi of children who are at risk of developing BD [96]. Singh et al. reported atypical patterns of prefrontal and subcortical intrinsic connectivity in the healthy offspring of parents with BD [97]. Abnormalities in amygdala development and in other regions of the limbic system (e.g., the hypothalamic nuclei) in BD were also found in structural and functional neuro-imaging 
studies $[98,93]$. It has been suggested that such neuroanatomical changes that occurred at a very early stage of BD could partly explain the increased vulnerability to environmental stress that is observed in at-risk youths $[9,14,6,12]$.

\section{$\underline{\text { Limitations and further research }}$}

In recent decades, studies on biological and neuroimaging biomarkers have led to a better understanding of the physiopathological mechanisms that are involved in BD. Moreover, the lack of specificity of current risk factors and prodromal clinical symptoms strongly supports the developing of biomarkers to identify youths who have a higher risk of developing BD. Ideally, biomarkers will help to measure the accurate risk of developing BD and guide treatment in youths with non-specific symptoms (e.g., for adolescents who are referred for a first episode of depression) [99]. Encouraging findings that concern the inflammatory biomarkers at a later stage of BD have been examined in adults, but few studies have been conducted in youths. Preliminary studies should be replicated in larger samples and should use a longitudinal design to test the predictive validity of such biomarkers. Because much focus is put on the sensitivity of putative biomarkers, too little attention is paid to their specificity. For example, Mesman et al. reported that the abnormal expressions of genes that are involved in inflammation did not differ between youths who have developed a mood disorder, those who have developed a non-mood disorder, and those who have not developed any psychiatric disorder [87]. In contrast, Padmos et al. noted that monocyte gene activation, which is found in adolescent bipolar offspring, might potentially predict the development of mood disorders [86]. Moreover, the identification of one biomarker as a predictor for both BD and other psychiatric disorders, such as psychosis disorders, could also reflect the overlap 
between these diseases. Further studies would be needed to assess the extent to which biomarkers are specific to BD or reflect a general vulnerability to psychiatric disorders.

\section{(iv) Efficacy of preventive interventions}

The objectives of a preventive intervention are to reduce early symptoms, enhance the ability to cope with dependent and independent stressors, and prevent or delay the onset of a disorder [100]. Psychosocial and pharmacological treatments have been proposed as preventive interventions for youths who are at risk of BD.

\section{$\underline{\text { Psychosocial interventions }}$}

The use of psychoeducational or psychotherapeutic interventions as a first step to preventing $\mathrm{BD}$ has been proposed, given the favourable benefit/risk ratio and the greater level of satisfaction among young patients and their families when compared to pharmacological treatment [101]. Four studies have been conducted to evaluate the efficacy of psychosocial interventions in children who are at risk of BD [102-105]. Nadkarni and Fristad examined the effect of multi-family psycho-educational psychotherapy for 8 weeks on 17 subjects with depressive symptoms [102]. A lower conversion rate to BD spectrum disorders was observed in the treated group after a 1-year follow-up. In an open study, which was conducted in 13 children of adults with BD with subthreshold mood symptoms, an improvement in symptomatology and functioning levels after a 1-year follow-up was found in youths who received Family Focused Therapy for High Risk children (FFT-HR), in addition to their usual treatment [103]. FFT-HR was associated with a faster recovery in a controlled randomised 
trial conducted in 40 subjects over 12 months [104]. Interpersonal and Social Rhythm Therapy (IPSRT), which targets altered social and sleep patterns, showed encouraging findings in a pilot study conducted on 13 youths [105]. A randomised controlled multi-centre clinical trial is being conducted to evaluate the efficacy and safety of a specific cognitivebehavioural psychotherapy (CBT) for young people who are at risk of BD [106].

\section{Pharmacotherapy interventions}

Although mood stabilisers and atypical antipsychotic medications exhibit efficacy for the curative treatment of manic episodes in adolescents [107,108], their efficacies in the treatment of prodromal mood symptoms are largely unknown. Thus far, only four studies have been conducted to evaluate their efficacy in this context [109-112]. A study on 30 youths who suffered from prepubertal major depressive disorder, with putative predictors of future $\mathrm{BD}$, was performed to evaluate the efficacy of lithium. In this 6-week, double-blind, placebo-controlled trial, lithium was not found to be more efficacious than the placebo. However, the effect of lithium on the prevention of the onset of BD was not examined [109]. The effect of valproate sodium was evaluated in a 12-week open trial that included 24 children with first-degree relatives with $\mathrm{BD}$ and major depressive disorder, cyclothymic, dysthymic, attention-deficit/hyperactivity disorder, or other affective symptoms. Of the 23 subjects who completed the trial, $18(78 \%)$ were considered to be "very much improved" or "much improved" [112]. A randomised, placebo-controlled study was conducted to evaluate the efficacy of valproate sodium in 56 youths who had at least one biological parent who suffered from BD, BD-NOS, or cyclothymia. After 5 years of follow-up, the treated group did not differ from the placebo group with respect to the survival time to the discontinuation of medication (the primary study outcome variable) or discontinuation due to a mood event 
[110]. The effect of quetiapine has been evaluated in a 12 -week open trial in 20 adolescents with first-degree relatives with BD-NOS, BD-II, dysthymia or major depressive disorder, with a response rate of approximately $87 \%$ [111]. Different authors have suggested that in the early phases, intervention should focus on non-specific neuroprotective strategies and psychosocial intervention, while considering the few potential side effects compared to lithium or antipsychotics $[113,80,114,115]$. McNamara et al. recommended that patients with prodromal symptoms should be treated using omega-3 fatty acids and vitamins [113]. Preclinical and clinical studies supported the positive impact of omega-3 fatty supplementation for reducing depressive symptom severity in children and adolescents with mood disorder [116]. Favourable effects of omega-3 fatty supplementation were observed in the case of bipolar depression, and manic episodes, according to a meta-analysis of five clinical trials conducted in BD patients [117]. Patients who fulfil the criteria for BD should be treated in accordance with current recommendations for manic or hypomanic episodes.

\section{Limitations and further research}

The scientific evidence that is available with regard to the effects of psychotherapeutic interventions is dramatically insufficient for meeting the needs of clinicians. The effect of interventions that target environmental risk factors (e.g., substance use) has not been properly evaluated on the future risk of developing BD [107,26,18]. The neuroprotective effect of antiinflammatory agents must be evaluated on youths who are at risk of BD.

\section{Staging models to define individual subthresholds for intervention}




\section{$\underline{\text { Different staging models }}$}

Given the consequences of a delayed intervention and the importance of long-term tolerability, models that are based on a measure of individual risk for developing BD have been proposed. Clinical staging models have been proposed as a rational method to classify patients according to their level of risk of developing BD [100,118-122,113]. They provide a framework that could help to implement a gradual approach for the interventions. For example, safe and well-tolerated interventions could be proposed at an early stage, although treatments that are more likely to be associated with adverse effects should be reserved for those who have a higher risk for transition [123]. Table 2 presents the staging models that were proposed for BD and the definition of the stages for each one. It should be noted that certain staging models, such as those developed by Berk or Kapczinski, do not specifically focus on the transition to $\mathrm{BD}$ and instead encompass all of the natural courses of the disease, from an early stage without specific symptoms (e.g., stage 0 in Berk's model) to a severe form (e.g., stage 4 in Berk's model) [124,6,31].

[Insert Table 2 about here]

Three staging models were specifically developed to focus on the transition from the at-risk stage to the onset of a first manic or hypomanic episode [100,120,121]. These models are based on specific scales to measure different risk factors (as illustrated in Table 1) and to detect psychopathological and functional impairments that precede the onset of BD. Corell et al. developed the "Bipolar Prodrome Symptom Scale Prospective" (BPSS-P) by 
retrospectively questioning child and adolescent patients who had experienced their first manic episode [100]. Bechdolf et al. operationalised the category of "Bipolar at Risk" (BAR) by analogy to the Ultra-High-Risk criteria for psychosis [119]. Leopold et al. set up the "Early Phase Inventory for Bipolar Disorders" (EPIbipolar) which is based on a systematic review of the literature that concerns putative risk factors for developing BD in young adults [121]. The notions of "subclinical-attenuated" [100], "subthreshold manic symptoms" [119] and "subthreshold affective symptoms" [121] are based on findings from prospective studies that were conducted on the general population, in the offspring of patients with $\mathrm{BD}$, in people with unipolar depression and in retrospective studies on BD patients. Berk et al. proposed a staging model that encompassed all of the natural history of $\mathrm{BD}$, from the early, pre-risk status to severe persistent disease [124]. This model focussed more specifically on the distinct neurobiological correlates of the stages of the disorder. The description of each stage referred to not only the clinical symptoms but also the functional impairments and cognitive difficulties. This initial model was further developed by Kapczinski [6]; their work emphasised the assessment of patients in the inter-episodic period and included a latent phase and four stages.

\section{$\underline{\text { Validity of staging models }}$}

A staging model should be able to classify patients according to their level of severity and to predict a transition to the subsequent stages. Table 3 shows the studies that were conducted to measure the validity of the staging models, in particular the predictive value (i.e., the possibility of discriminating between different levels of BD) and the reliability (i.e., the adequacy of staging between and within the raters). 
[Insert Table 3 about here]

Corell et al. found a good internal validity and inter-rater reliability of the BPSS-P when applied to 205 referred youths [118]. However, no information was available on the predictive value of the BPSS-P score. Leopold et al. found $16 \%$ of youths to be at risk of BD in a referred sample [122]. The measure of the internal consistency of EPIBipolar was not reported in the study. Considering the cross-sectional design of the study, the transition rate of this group is not known. Bechdolf et al. followed BAR screen-positive individuals $(n=35)$ and a matched control $(n=35)$ over a period of 12 months [120]. The clinicians who made the diagnoses were blind to the at-risk group allocation. Five cases out of 35 made the transition to the first hypomanic/manic episode during the follow-up. The differences between the subgroups were not significant. A previous study reported a good inter-rater reliability with regard to the Comprehensive Assessment of At-Risk Mental States scale that was used to identify the at-risk youths [119]. The distinction between the different groups in the staging model proposed by Berk is supported by longitudinal studies, which have stressed the progressive increase of residual thymic symptoms, cognitive difficulties and functional impairments during the course of the disorder. Reinares et al. used latent class analysis to define the subtypes of patients with BD [125]. Two groups were identified; they differed by the episode density (the total number of episodes divided by the duration of the illness), level of residual depressive symptoms, estimated verbal intelligence and inhibitory control. Such findings support the use of both cognitive difficulties and persistent symptoms for assigning individual patients into prognostic classes in staging models. Rosa et al. compared the functional impairments and cognitive impairments that were presented by 87 referred patients according to the levels of the staging models [126]. They found a linear association between the severity of the functional impairment and the clinical stages. Moreover, the patients in 
group III and group IV presented worse cognitive measures than the healthy controls. Further studies are needed to measure the transition rate from one stage to the other using longitudinal data.

\section{$\underline{\text { Limitations and further research }}$}

Staging models must be better operationalised and validated by empirical longitudinal research. Only one study has examined the predictive value of staging models on longitudinal data [120]. Because more focus has been placed on sensitivity, few studies have discussed the problems of the specificity of the staging models. Further studies are needed to explore the possibility of pluripotent models for serious mental illness [21]; Fusar-Poli suggested that focus should be placed on a general at-risk presentation ("Ultra High-Risk") to prevent both psychosis and non-psychosis disorders [71]. Furthermore, the role of biomarkers in increasing the predictive value of the staging models, especially at an early stage, deserves further investigation.

\section{Conclusions}

The consideration of minor symptoms as risk factors for the development of complete mental disorders and as targets for preventive interventions represents a major paradigm shift in psychiatry. The social burden of $\mathrm{BD}$ and the poorer prognoses in the case of delayed treatment make the development of preventive interventions essential. In this paper, the principal limitation for a preventive approach to BD in children and adolescents concerns the 
lack of specificity of clinical and non-clinical markers. In particular, promising evidence with

regard to the development of biomarkers exists, but it should be regarded as largely

preliminary. Despite encouraging results that support the benefits of staging models in BD,

the algorithms that have been developed still need to be more empirically validated in

children and adolescents.

\section{References}

1. Lish JD, Dime-Meenan S, Whybrow PC, Price RA, Hirschfeld RM (1994) The National Depressive and Manic- Depressive Association (NDMDA) survey of bipolar members. Journal of Affective Disorders 31:281-294

2. Perlis RH, Miyahara S, Marangell LB, Wisniewski SR, Ostacher M, DelBello MP, Bowden CL, Sachs GS, Nierenberg AA (2004) Long-term implications of early onset in bipolar disorder: data from the first 1000 participants in the Systematic Treatment Enhancement Program for Bipolar Disorder (STEP-BD). Biological Psychiatry 55:875-881. doi:10.1016/j.biopsych.2004.01.022 3. Gore FM, Bloem PJN, Patton GC, Ferguson J, Joseph V, Coffey C, Sawyer SM, Mathers CD (2011) Global burden of disease in young people aged 10-24 years: a systematic analysis. Lancet 377:2093-2102

4. Halfon O, Laget J, Barrie M (1995) An epidemiological and clinical approach to adolescent suicide. A comparison between suicidal and non-suicidal clinical groups in a health foundation center for French students. Eur Child Adolesc Psychiatry 4 (1):32-38

5. Baver M, Glenn T, Grof P, Schmid R, Pfennig A, Whybrow PC (2010) Subsyndromal mood symptoms: a useful concept for maintenance studies of bipolar disorder? . Psychopathology 43:1-7

6. Kapczinski F, V.V. D, Kauer-Sant'Anna M, Frey BN, Grassi-Oliveira R, Colom F, Berk M (2009) Clinical implications of a staging model for bipolar disorders. Expert Review of Neurotherapeutics 9:957-966. doi:10.1016/j.pnpbp.2009.07.027

7. Tohen M, Waternaux CM, Tsuang MT (1990) Outcome in mania: a 4-year prospective follow-up of 75 patients utilizing survival analysis. Archives of General Psychiatry 47:1 106-1111

8. Post RM, Leverich GS, Kupka RW, Keck PE, McElroy SL, Altshuler LL, Frye MA, Luckenbaugh DA, Rowe M, Grunze H, Suppes T, Nolen WA (2010) Early-onset bipolar disorder and treatment delay are risk factors for poor outcome in adulthood. Journal of Clinical Psychiatry 71:864-872 9. Berk M, Brnabic A, Dodd S, Kelin K, Tohen M, Malhi GS, Berk L, Conus P, McGorry PD (2011) Does stage of illness impact treatment response in bipolar disorder? Empirical treatment data and their implication for the staging model and early intervention. Bipolar Disorders 13:87-98. doi:10.1111/j.1399-5618.2011.00889.x

10. Angst J, Sellaro R (2000) Historical perspectives and natural history of bipolar disorder. Biol Psychiatry $48(6): 445-457$

11. Turvey CL, Coryell WH, Arndt S, Solomon DA, Leon AC, Endicott J, Mueller T, Keller M, Akiskal H (1999) Polarity sequence, depression, and chronicity in bipolar I disorder. J Nerv Ment Dis 187 (3):181-187

12. Robinson LJ, Ferrier IN (2006) Evolution of cognitive impairment in bipolar disorder: a systematic review of cross-sectional evidence. Bipolar Disorders 8:103-116

13. Torres IJ, Boudreau VG, Yatham LN (2007) Neuropsychological functioning in euthymic bipolar disorder: a meta-analysis. Acta Psychiatrica Scandinavica 434:17-26 
14. Baver IE, Pascoe MC, Wollenhaupt-Aguiar B, Kapczinski F, Soares JC (2014) Inflammatory mediators of cognitive impairment in bipolar disorder. Journal of Psychiatric Research 56:1827. doi:10.1016/j.jpsychires.2014.04.017

15. López-Jaramillo C, Lopera-Vásquez J, Gallo A, Ospina-Duque J, Bell V, Torrent C, Martínez-Arán A, Vieta E (2010) Effects of recurrence on the cognitive performance of patients with bipolar I disorder: implications for relapse prevention and treatment adherence. Bipolar Disorders 12:557-567

16. Tohen M, Hennen J, Zarate Jr. CM, Baldessarini RJ, Strakowski SM, Stoll AL, Faedda GL, Suppes T, Gebre-Medhin P, Cohen BM (2000) Two-year syndromal and functional recovery in 219 cases of first-episode major affective disorder with psychotic features. American Journal of Psychiatry 157:220-228

17. Rosa AR, Reinares M, Amann B, Popovic D, Franco C, Comes M, Torrent C, Bonnin CM, Sole B, Valenti M, Salamero M, Kapczinski F, Vieta E (2011) Six-month functional outcome of a bipolar disorder cohort in the context of a specialized-care program. Bipolar Disorders 13:679686

18. Malhi GS, Bargh DM, Coulston CM, Das P, Berkc M (2014) Predicting bipolar disorder on the basis of phenomenology: implications for prevention and early intervention. Bipolar Disorders 16:455-470. doi:10.1111/bdi.12133

19. Dean BB, Gerner D, Gerner RH (2004) A systematic review evaluating health-related quality of life, work impairment and health-care costs and utilization in bipolar disorders. Current Medical Research and Opinion 20:139-154

20. Goldberg JF, Ernst CL (2002) Features associated with the delayed initiation of mood stabilizers at illness onset in bipolar disorder. Journal of Clinical Psychiatry 63:985-991

21. Conus P, Macneil C, McGorry PD (2014) Public health significance of bipolar disorder: implications for early intervention and prevention. Bipolar Disorders 16:548-556. doi:10.1111/bdi.12137

22. Ketter TA, Houston JP, Adams DH, Risser RC, Meyers AL, Williamson DJ, Tohen M (2006) Differential efficacy of olanzapine and lithium in preventing manic or mixed recurrence in patients with bipolar I disorder based on number of previous manic or mixed episodes. Journal of Clinical Psychiatry 67:95-101

23. Berghofer A, Alda M, Adli M, Baethge C, Baver M, Bschor T, Grof P, Muller-Oerlinghausen B, Rybakowski JK, Suwalska A, Pfennig A (2013) Stability of lithium treatment in bipolar disorder - long-term follow-up of 346 patients. Int J Bipolar Disord 1:11. doi:10.1 186/2194-751 1-1-11

24. Scott J, Paykel E, Morriss R, Bentall R, Kinderman P, Johnson T, Abbott R, Hayhurst H (2006) Cognitive-behavioural therapy for severe and recurrent bipolar disorders: randomised controlled trial. British Journal of Psychiatry 188:313-320

25. Colom F, Reinares M, Pacchiarotti I, Popovic D, Mazzarini L, Martinez AA, Torrent C, Rosa AR, Palomino-Otiniano R, Franco C, Bonnin CM, Vieta E (2010) Has number of previous episodes any effect on response to group psychoeducation in bipolar patients?. Acta Neuropsychiatrica 22:50-53

26. Reinares M, Sánchez-Moreno J, Fountoulakis KN (2014) Psychosocial interventions in bipolar disorder: What, for whom, and when. Journal of Affective Disorders 156:46-55. doi:10.1016/j.jad.2013.12.017

27. Lam DH, Burbeck R, Wright K, Pilling S (2009) Psychological therapies in bipolar disorder: the effect of illness history on relapse prevention-a systematic review. Bipolar Disorders $11: 474-482$

28. Alda M (2004) The phenotypic spectra of bipolar disorder. Eur Neuropsychopharmacol 14 Suppl 2:S94-99. doi:10.1016/j.euroneuro.2004.03.006

29. Grof P, Alda M, Ahrens B (1995) Clinical course of affective disorders: were Emil Kraepelin and Jules Angst wrong? Psychopathology 28 Suppl 1:73-80

30. Chang KD (2010) Course and impact of bipolar disorder in young patients. Journal of Clinical Psychiatry 71:e05

31. Brietzke E, Mansur RB, Soczynska JK, Kapczinski F, Bressan RA, McIntyre RS (2012) Towards a multifactorial approach for prediction of bipolar disorder in at risk populations. Journal of Affective Disorders 140:82-91. doi:10.1016/j.jad.2012.02.016 
32. Hasler G, Drevets WC, Gould TD, Gottesman II, Manji HK (2006) Toward constructing an endophenotype strategy for bipolar disorders. Biological Psychiatry 60:93-105

33. Geller B, Craney JL, Bolhofner K, Nickelsburg MJ, Williams M, Zimerman B (2002) Two-year prospective follow-up of children with a prepubertal and early adolescent bipolar disorder phenotype. Am J Psychiatry 159 (6):927-933

34. Green JG, McLaughlin KA, Berglund PA, Gruber MJ, Sampson NA, Zaslavsky AM, Kessler RC (2010) Childhood adversities and adult psychiatric disorders in the national comorbidity survey replication I: associations with first onset of DSM-IV disorders. Arch Gen Psychiatry 67 (2):113-123. doi:10.1001/archgenpsychiatry.2009.186

35. Hillegers MH, Reichart CG, Wals M, Verhulst FC, Ormel J, Nolen WA (2005) Five-year prospective outcome of psychopathology in the adolescent offspring of bipolar parents. Bipolar Disord 7 (4):344-350. doi:10.1111/j.1399-5618.2005.00215.x

36. Duffy A, Alda M, Crawford L, Milin R, Grof P (2007) The early manifestations of bipolar disorder: a longitudinal prospective study of the offspring of bipolar parents. Bipolar Disorders 9:828-838

37. Kessler RC, Crum RM, Warner LA, Nelson CB, Schulenberg J, Anthony JC (1997) Lifetime co-occurrence of DSM-III-R alcohol abuse dependence with other psychiatry disorders in the National Comorbidity Survey. Archives of General Psychiatry 54:313-321

38. Baethge C, Hennen J, Khalsa HMK, Salvatore P, Tohen M, Baldessarini RJ (2008) Sequencing of substance use and affective morbidity in 166 first-episode bipolar I disorder patients. Bipolar Disorders 10:738-741

39. Duffy A, Horrocks J, Doucette S, Keown-Stoneman C, McCloskey S, Grof P (2014) The developmental trajectory of bipolar disorder. The British Journal of Psychiatry 204:122-128. doi:10.1192/bjp.bp.113.126706

40. Reiehart CG, Nolen WA (2004) Earlier onset of bipolar disorder in children by antidepressants or stimulants? A hypothesis. Journal of Affective Disorders 78:81-84

41. Tillman R, Geller B (2006) Controlled study of switching from attention-deficit/hyperactivity disorder to a prepubertal and early adolescent bipolar I disorder phenotype during 6-year prospective follow-up: rate, risk, and predictors. Development and Psychopathology 18:10371053

42. Goldsmith M, Singh M, Chang K (2011) Antidepressants and psychostimulants in pediatric populations: is there an association with mania? Paediatric Drugs 13:225-243

43. Meyer SE, Carlson GA, Wiggs EA, Ronsaville DS, Martinez PE, Klimes-Dougan B, Gold PW, Radke-Yarrow M (2006) A prospective high-risk study of the association among maternal negativity, apparent frontal lobe dysfunction, and the development of bipolar disorder. Development and Psychopathology 18:573-589

44. Hirschfeld RM, Lewis L, Vornik LA (2003) Perceptions and impact of bipolar disorder: how far have we really come? Results of the national depressive and manic-depressive association 2000 survey of individuals with bipolar disorder. J Clin Psychiatry 64 (2):161-174

45. Rucklidge JJ (2008) Retrospective parent report of psychiatric histories: do checklists reveal specific prodromal indicators for postpubertal-onset pediatric bipolar disorder? Bipolar Disord 10 (1):56-66. doi:10.1111/j.1399-5618.2008.00533.x

46. Fergus EL, Miller RB, Luckenbaugh DA, Leverich GS, Findling RL, Speer AM, Post RM (2003) Is there progression from irritability/dyscontrol to major depressive and manic symptoms? A retrospective community survey of parents of bipolar children. J Affect Disord 77 (1):71-78

47. Skjelstad DV, Malt UF, Holte A (2010) Symptoms and signs of the initial prodrome of bipolar disorder. A systematic review. Journal of Affective Disorders 126:1-13. doi:10.1016/j.jad.2009.10.003

48. Birmaher B, Axelson D, Strober M, Gill MK, Valeri S, Chiappetta L, Ryan N, Leonard H, Hunt J, lyengar S, Keller M (2006) Clinical course of children and adolescents with bipolar spectrum disorders. Arch Gen Psychiatry 63 (2):175-183. doi:10.1001/archpsyc.63.2.175

49. Axelson DA, Birmaher B, Strober MA, Goldstein BI, Ha W, Gill MK, Goldstein TR, Yen S, Hower H, Hunt JI, Liao F, lyengar S, Dickstein D, Kim E, Ryan ND, Frankel E, Keller MB (2011) Course of subthreshold bipolar disorder in youth: diagnostic progression from bipolar disorder not otherwise specified. Journal of the American Academy of Child and Adolescent Psychiatry 50:1001-1016. doi:10.1016/j.jaac 
50. Kochman FJ, Hantouche EG, Ferrari P, Lancrenon S, Bayart D, Akiskal HS (2005) Cyclothymic temperament as a prospective predictor of bipolarity and suicidality in children and adolescents with major depressive disorder. Journal of Affective Disorders 85:181-189. doi:10.1016/j.jad.2003.09.009

51. Akiskal HS, Maser JD, Zeller PJ, Endicott J, Coryell W, Keller M, Warshaw M, Clayłon P, Goodwin F (1995) Switching from 'unipolar' to bipolar II: an 11-year prospective study of clinical and temperamental predictors in 559 patients. Archives of General Psychiatry 52 (114-123)

52. Kim-Cohen J, Caspi A, Moffitt TE, Harrington H, Milne BJ, Poulton R (2003) Prior juvenile diagnoses in adults with mental disorder: developmental follow-back of a prospectivelongitudinal cohort. Arch Gen Psychiatry 60 (7):709-717. doi:10.1001/archpsyc.60.7.709

53. Costello EJ, Angold A, Burns BJ, Erkanli A, Stangl DK, Tweed DL (1996) The Great Smoky Mountains Study of Youth. Functional impairment and serious emotional disturbance. Arch Gen Psychiatry 53 (12):1137-1143

54. Johnson JG, Cohen P, Brook JS (2000) Associations between bipolar disorder and other psychiatric disorders during adolescence and early adulthood: a community-based longitudinal investigation. Am J Psychiatry 157 (10):1679-1681

55. Paaren A, Bohman H, von Knorring L, Olsson G, von Knorring AL, Jonsson U (2014) Early risk factors for adult bipolar disorder in adolescents with mood disorders: a 15-year follow-up of a community sample. BMC Psychiatry 14 (1):363. doi:10.1186/s12888-014-0363-z

56. Akiskal HS, Downs J, Jordan P, Watson S, Daugherty D, Pruitt DB (1985) Affective disorders in referred children and younger siblings of manic-depressives. Mode of onset and prospective course. Arch Gen Psychiatry 42 (10):996-1003

57. Shaw JA, Egeland JA, Endicott J, Allen CR, Hostetter AM (2005) A 10-year prospective study of prodromal patterns for bipolar disorder among Amish youth. J Am Acad Child Adolesc Psychiatry 44 (11):1 104-1111. doi:10.1097/01.chi.0000177052.26476.e5

58. Egeland JA, Endicott J, Hostetter AM, Allen CR, Pauls DL, Shaw JA (2012) A 16-year prospective study of prodromal features prior to BPI onset in well Amish children. J Affect Disord 142 (1-3):186-192. doi:10.1016/j.jad.2012.04.023

59. Axelson D, Goldstein B, Goldstein T, Monk K, YU H, Hickey MB, Sakolsky D, Diler R, Hafeman D, Merranko J, lyengar S, Brent D, Kupfer D, Birmaher B (2015) Diagnostic Precursors to Bipolar Disorder in Offspring of Parents With Bipolar Disorder: A Longitudinal Study. Am J Psychiatry:appiajp201414010035. doi:10.1176/appi.ajp.2014.14010035

60. Harrington R, Myatt T (2003) Is preadolescent mania the same condition as adult mania? A British perspective. Biological Psychiatry 53:961-969. doi:10.1016/S0006-3223(03)00315-9

61. Consoli A, Cohen D (2013) Manic-like symptoms in youths: Diagnosis issues and controversies. Neuropsychiatrie de l'Enfance et de l'Adolescence 61:154-159

62. Stringaris A, Baroni A, Haimm C, Brotman M, Lowe CH, Myers F, Rustgi E, Wheeler W, Kayser R, Towbin K, Leibenluft E (2010) Pediatric bipolar disorder versus severe mood dysregulation: risk for manic episodes on follow-up. J Am Acad Child Adolesc Psychiatry 49 (4):397-405

63. Masi G, Perugi G, Toni C, Millepiedi S, Mucci M, Bertini N, Akiskal HS (2006) The Clinical Phenotypes of Juvenile Bipolar Disorder:Toward a Validation of the Episodic-ChronicDistinction. . Biological Psychiatry 59:603-610. doi:10.1016/j.biopsych.2005.08.034

64. Leibenluft E, Cohen P, Gorrindo T, Brook JS, Pine DS (2006) Chronic versus episodic irritability in youth: a community-based, longitudinal study of clinical and diagnostic associations. J Child Adolesc Psychopharmacol 16 (4):456-466. doi:10.1089/cap.2006.16.456

65. Duffy A (2010) The early natural history of bipolar disorder: what we have learned from longitudinal high-risk research. Can J Psychiatry 55 (8):477-485

66. Hegerl U, Bottner AC, Holtschmidt-Täschner B, Born C, Seemüller F, Scheunemann W, Schütze M, Grunze H, Henkel V, Mergl R, Angst J (2008) Onset of depressive episodes is faster in patients with bipolar versus unipolar depressive disorder: evidence from a retrospective comparative study. Journal of Clinical Psychiatry 69:1075-1080

67. Strober M, Carlson G (1982) Bipolar illness in adolescents with major depression: clinical, genetic, and psychopharmacologic predictors in a three- to four-year prospective follow-up investigation. Archives of General Psychiatry 39:549-555 
68. Consoli A, Soultanian C, Tanguy ML, Laurent C, Perisse D, Luque D, Berrios G, Cohen D (2007) Cotard's Syndrome in Adolescents and Young Adults is Associated with an Increased Risk of Bipolar Disorder. Bipolar Disorders 9:665-668

69. Birmaher B, Arbelaez C, Brent D (2002) Course and outcome of child and adolescent major depressive disorder. Child and Adolescent Psychiatric Clinics of North America 11:619637

70. Cicchetti D, Hinshaw SP (2003) Conceptual, methodological, and statistical issues in developmental psychopathology: a special issue in honor of Paul E. Meehl. Dev Psychopathol 15 (3):497-499

71. Fusar-Poli P, Yung AR, McGorry P, van Os J (2014) Lessons learned from the psychosis highrisk state: towards a general staging model of prodromal intervention. Psychological Medicine 44:17-24. doi:10.1017/S0033291713000184

72. Gottesman I, Gould TD (2003) The endophenotype concept in psychiatry: Etymology and strategic intentions. American Journal of Psychiatry 160:636-645

73. Goldstein BI, Young LT (2013) Toward Clinically Applicable Biomarkers in Bipolar Disorder: Focus on BDNF, Inflammatory Markers, and Endothelial Function. Current Psychiatry Reports 15:2-7. doi:10.1007/s1 1920-013-0425-9

74. Singh MK, DelBello MP, Strakowski SM (2008) Temperament in child offspring of parents

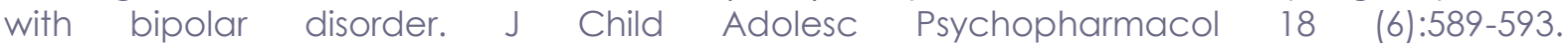
doi:10.1089/cap.2007.142

75. Duffy A, Alda M, Trinneer A, Demidenko N, Grof P, Goodyer IM (2007) Temperament, life events, and psychopathology among the offspring of bipolar parents. Eur Child Adolesc Psychiatry 16 (4):222-228. doi:10.1007/s00787-006-0592-x

76. Evans L, Akiskal HS, Keck J, McElroy SL, Sadovnick AD, Remick RA, Kelsoe JR (2005) Familiality of temperament in bipolar disorder: support for a genetic spectrum. Journal of Affective Disorders 85:153-168

77. Chang KD, Blasey CM, Ketter TA, Steiner H (2003) Temperament characteristics of child and adolescent bipolar offspring. J Affect Disord 77 (1):1 1-19

78. Doucette S, Horrocks J, Grof P, Keown-Stoneman C, Duffy A (2013) Attachment and temperament profiles among the offspring of a parent with bipolar disorder. J Affect Disord 150 (2):522-526. doi:10.1016/j.jad.2013.01.023

79. Ellenbogen MA, Hodgins S, Walker CD, Couture S, Adam S (2006) Daytime cortisol and stress reactivity in the offspring of parents with bipolar disorder. Psychoneuroendocrinology 31:1164-1180

80. Berk M, Kapczinski F, Andreazza AC, Dean OM, Giorlando F, Maes M, Yücel M, Gama CS, Dodd S, Dean B, Magalhães PV, Amminger P, McGorry P, Malhi GS (2011) Pathways underlying neuroprogression in bipolar disorder: focus on inflammation, oxidative stress and neurotrophic factors. Neuroscience \& Biobehavioral Reviews 35:804-817

81. Brown NC, Andreazza AC, Young LT (2014) An updated meta-analysis of oxidative stress markers in bipolar disorder. Psychiatry Research 218:61-68. doi:10.1016/j.psychres.2014.04.005

82. Andreazza AC, Kapczinski F, Kaver-Sant'Anna M, Walz JC, Bond DJ, Gonçalves CA, Young LT, Yatham LN (2009) MBBS 3-Nitrotyrosine and glutathione antioxidant system in patients in the early and late stages of bipolar disorder. Journal of Psychiatry \& Neuroscience 34:263-271

83. Kaver-Sant'anna M, Kapczinski FF, Andreazza AC, Bond DJ, Lam RW, Young LT, Yatham LN (2009). Brain-derived neurotrophic factor and inflammatory markers in patients with earlyvs. late-stage bipolar disorder. International Journal of Neuropsychopharmacology 12:447458. doi:10.1017/S1461145708009310

84. Fernandes BS, Gama CS, Ceresér KM, Yatham LN, Fries GR, Colpo G, de Lucena D, Kunz M. Gomes FA, Kapczinski F (2011) Brain-derived neurotrophic factor as a state-marker of mood episodes in bipolar disorders: a systematic review and meta-regression analysis. Journal of Psychiatric Research 45:995-1004

85. Grande I, Magalhães PV, Chendo I, Stertz L, Panizutti B, Colpo GD, Rosa AR, Gama CS, Kapczinski F, Vieta E (2014) Staging bipolar disorder: clinical, biochemical, and functional correlates. Acta Psychiatr Scand 129:437-444. doi:10.1111/acps.12268 
86. Padmos RC, Hillegers MH, Knijff EM, Vonk R, Bouvy A, Staal FJT, de Ridder D, Kupka RW, Nolen WA, Drexhage HA (2008) A discriminating messenger RNA signature for bipolar disorder formed by an aberrant expression of inflammatory genes in monocytes. Archives of General Psychiatry 65:395-407

87. Mesman E, Hillegers MHJ, Ambree O, Arolt V, Nolen WA, Drexhage HA (2014) Monocyte activation, brain-derived neurotrophic factor (BDNF), and S100B in bipolar offspring: a followup study from adolescence into adulthood. Bipolar Disorders. doi:10.1111/bdi.12231

88. Zalla T, Joyce C, Szoke A, Schurhoff F, Pillon B, Komano O, Perez-Diaz F, Bellivier F, Alter C, Dubois B, Rouillon F, Houde O, Leboyer M (2004) Executive dysfunctions as potential markers of familial vulnerability to bipolar disorder and schizophrenia. Psychiatry Research 121:207-217 89. Brotman MA, Guyer AE, Lawson ES, Horsey SE, Rich BA, Dickstein DP, Pine DS, Leibenluft E (2008) Facial emotion labeling deficits in children and adolescents at risk for bipolar disorder. American Journal of Psychiatry 165:385-389. doi:10.1097/CHI

90. Schenkel LS, Marlow-O'Connor M, Moss M, Sweeney JA, Pavuluri MN (2008) Theory of mind and social inference in children and adolescents with bipolar disorder. . Psychological Medicine 38:791-800. doi:10.1017/S0033291707002541

91. Whitney J, Howe M, Shoemaker V, Li S, Sanders EM, Dijamco C, Acquaye T, Phillips J, Singh M. Chang K (2013) Socio-emotional Processing and Functioning of Youth at High Risk for Bipolar Disorder. Journal of Affective Disorders 148:112-117. doi:10.1016/j.jad.2012.08.016

92. Frey BN, Zunta-Soares GB, Caetano SC, Nicoletti MA, Hatch JP, Brambilla P, Mallinger AG, Soares JC (2008) Illness duration and total brain gray matter in bipolar disorder: evidence for neurodegeneration? European Neuropsychopharmacology 18:712-722

93. Strakowski SM, Adler CM, Almeida J, Altshuler LL, Blumberg HP, Chang KD, DelBello MP, Frangou S, Mclntosh A, Phillips ML, Sussman JE, Townsend JD (2012) The functional neuroanatomy of bipolar disorder: a consensus model. Bipolar Disorders 14:313-325

94. Strakowski SM, DelBello MP, Zimmerman ME, Getz GE, Mills NP, Ret J, Shear P, Adler CM (2002) Ventricular and periventricular structural volumes in first- versus multiple-episode bipolar disorder. American Journal of Psychiatry 159:1841-1847

95. Arango C, Rapado-Castro M, Reig S, Castro-Fornieles J, Gonzalez-Pinto A, Otero S, Baeza I, Moreno C, Graell M, Janssen J, Parellada M, Moreno D, Bargallo N, Desco M (2012) Progressive brain changes in children and adolescents with first-episode psychosis. Arch Gen Psychiatry 69 (1):16-26. doi:10.1001/archgenpsychiatry.2011.150

96. Chang K, Adleman N, Dienes K, Barnea-Goraly N, Reiss A, Ketter T (2003) Decreased Nacetylaspartate in children with familial bipolar disorder. Biological Psychiatry 53:1059-1065

97. Singh MK, Chang KD, Kelley RG, Saggar M, Reiss AL, Gotlib IH (2014) Early signs of anomalous neural functional connectivity in healthy offspring of parents with bipolar disorder. Bipolar Disorders. doi:10.1111/bdi.12221

98. Pfeifer JC, Welge J, Strakowski SM, Adler CM, DelBello MP (2008) Meta-analysis of amygdala volumes in children and adolescents with bipolar disorder. Journal of the American Academy of Child and Adolescent Psychiatry 47:1289-1298

99. Fernandes BS, Gama CS, Kaver-Sant'Anna M, Lobato MI, Belmonte-de-Abreu P, Kapczinski $F$ (2009) Serum brain-derived neurotrophic factor in bipolar and unipolar depression: a potential adjunctive tool for differential diagnosis. Journal of Psychiatric Research 43:100-1204. doi:10.1016/j.jpsychires.2009.04.010

100. Correll CU, Penzner JB, Lencz T, Auther A, Smith CW, Malhotra AK, Kane JM, Cornblatt BA (2007) Early identification and high-risk strategies for bipolar disorder. Bipolar Disorders 9:324338

101. Pfennig A, Correll CU, Marx C, Rottmann-Wolf M, Meyer TD, Baver M, Leopold K (2014) Psychotherapeutic interventions in individuals at risk of developing bipolar disorder: a systematic review. Early Intervention in Psychiatry 8:3-11. doi:10.1111/eip.12082

102. Nadkarni RB, Fristad MA (2010) Clinical course of children with a depressive spectrum disorder and transient manic symptoms. Bipolar Disorders 12:494-503

103. Miklowitz DJ, Chang KD, Taylor DO, George EL, Singh MK, Schneck CD, Dickinson LM, Howe ME, J. G (2011) Early psychosocial intervention for youth at risk for bipolar I or II disorder: a one-year treatment development trial. Bipolar Disorders 13:67-75. doi:10.1111/j.1399$5618.2011 .00890 . x$ 
104. Miklowitz DJ, Schneck CD, Singh MK, Taylor DO, George EL, Cosgrove VE, Howe ME, Dickinson LM, Garber J, Chang KD (2013) Early intervention for symptomatic youth at risk for bipolar disorder: a randomized trial of family-focused therapy. Journal of the American Academy of Child and Adolescent Psychiatry 52:121-131

105. Goldstein TR, Fersch-Podrat R, Axelson DA, Gilbert A, Hlastala SA, Birmaher B, Frank E (2014) Intervention for Adolescents at High Risk for the Development of Bipolar Disorder: Pilot Study of Interpersonal and Social Rhythm Therapy (IPSRT). Psychotherapy 51:180-189. doi:10.1037/a0034396

106. Pfennig A, Leopold K, Bechdolf A, Correll CU, Holtmann M, Lambert M, Marx C, Meyer TD, Pfeiffer S, Reif A, Rottmann-Wolf M, Schmitt NM, Stamm T, Juckel G, Baver M (2014) Early specific cognitive-behavioural psychotherapy in subjects at high risk for bipolar disorders: stud protocol for a randomised controlled trial. . Trials 15:161. doi:10.1186/1745-6215-15-161

107. Consoli A, Deniau E, Huynh C, Purper D, Cohen D (2007) Treatments in child and adolescent bipolar disorders. European Child \& Adolescent Psychiatry 16:187-198

108. Birmaher B (2013) Bipolar disorder in children and adolescents. Child and Adolescent Mental Health 18:140-148. doi:10.1111/camh.12021

109. Geller B, Cooper TB, Zimerman B, Frazier J, Williams M, Heath J, Warner K (1998) Lithium for prepubertal depressed children with family history predictors of future bipolarity: a doubleblind, placebo-controlled study. Journal of Affective Disorders 51:165-175

110. Findling RL, Frazier TW, Youngstrom EA, McNamara NK, Stansbrey RJ, Gracious BL, Reed MD, Demeter CA, Calabrese JR (2007) Double blind, placebo-controlled trial of divalproex monotherapy in the treatment of symptomatic youth at high risk for developing bipolar disorder. Journal of Clinical Psychiatry 68 (781-788)

111. DelBello MP, Adler CM, Whitsel RM, Stanford KE, Strakowski SM (2007) A 12-week singleblind trial of quetiapine for the treatment of mood symptoms in adolescents at high risk for developing bipolar I disorder. Journal of Clinical Psychiatry 68:789-795

112. Chang KD, Dienes K, Blasey C, Adleman N, Ketter T, Steiner H (2003) Divalproex monotherapy in the treatment of bipolar offspring with mood and behavioral disorders and at least mild affective symptoms. Journal of Clinical Psychiatry 64:936-942

113. MCNamara RK, Nandagopal JJ, Strakowski SM, DelBello MP (2010) Preventative strategies for early-onset bipolar disorder: towards a clinical staging model. CNS Drugs 24:983-996

114. Milhiet V, Consoli A, Raffin M, Cohen D (2014) Lithium treatment in youths with bipolar disorder. . Annales Médico-psychologiques, revue psychiatrique 172 (3):219-228

115. Cohen D, Bonnot O, Bodeau N, Consoli A, Laurent C (2012) Adverse effects of secondgeneration antipsychotics in children and adolescents: a Bayesian meta-analysis. J Clin Psychopharmacol 32 (3):309-316

116. Grosso G, Pajak A, Marventano S, Castellano S, Galvano F, Bucolo C, Drago F, Caraci F (2014) Role of Omega-3 Fatty Acids in the Treatment of Depressive Disorders: A Comprehensive Meta-Analysis of Randomized Clinical Trials PLoS One 9 (5):e96905

117. Sarris J, Mischoulon D, Schweitzer I (2012) Omega-3 for bipolar disorder: meta-analyses of use in mania and bipolar depression. Journal of Clinical Psychiatry 73:81-86

118. Correll CU, Olvet DM, Auther AM, Hauser M, Kishimoto T, Carrión RE, Snyder S, Cornblatt BA (2014) The Bipolar Prodrome Symptom Interview and Scale-Prospective (BPSS-P): description and validation in a psychiatric sample and healthy controls. Bipolar Disorders 16:505-522. doi:10.1111/bdi.12209

119. Bechdolf A, Nelson B, Cotton SM, Chanen A, Thompson A, Kettle J, Conus P, Amminger P, Yung AR, Berk M, MCGorry PD (2010) A preliminary evaluation of the validity of at-risk criteria for bipolar disorders in help-seeking adolescents and young adults. Journal of Affective Disorders 127:316-320. doi:10.1016/j.jad.2010.06.016

120. Bechdolf A, Ratheesh A, Cotton SM, Nelson B, Chanen AM, Betts J, Bingmann T, Yung AR, Berk M, MCGorry PD (2014) The predictive validity of bipolar at-risk (prodromal) criteria in help-seeking adolescents and young adults: a prospective study. Bipolar Disorders 16:493504. doi:10.1111/bdi.12205 
121. Leopold K, Ritter P, Correll CU, Marx C, S. Ö, Juckel G, Baver M, Pfennig A (2012) Risk constellations prior to the development of bipolar disorders: rationale of a new risk assessment tool. Journal of Affective Disorders 136:1000-1010. doi:10.1016/j.jad.2011.06.043

122. Leopold K, Ratzer S, Correll CU, Rottmann-Wolf M, Pfeiffer S, Ritter P, Baver M, Pfennig A (2014) Characteristics, symptomatology and naturalistic treatment in individuals at-risk for bipolar disorders: Baseline results in the first 180 help-seeking individuals assessed at the dresden high-risk project. Journal of Affective Disorders 152-154:427-433. doi:10.1016/j.jad.2013.10.009

123. McGorry PD, Hickie IB, Yung AR, Pantelis C, Jackson HJ (2006) Clinical staging of psychiatric disorders: a heuristic framework for choosing earlier, safer and more effective interventions. Australian \& New Zealand Journal of Psychiatry 40:616-622

124. Berk M, Berk L, Dodd S, Cotton S, Macneil C, Daglas R, Conus P, Bechdolf A, Moylan S, Malhi G (2014) Stage managing bipolar disorder. Bipolar Disorders 16 (471-477). doi:10.1111/bdi.12099

125. Reinares M, Papachristou E, Harvey P, Bonnín M, Sánchez-Moreno J, Torrent C, AyusoMateos JL, Ploubidis GE, Vieta E, Frangou S (2013) Towards a clinical staging for bipolar disorder: Defining patient subtypes based on functional outcome. Journal of Affective Disorders 144:65-71. doi:10.1016/j.jad.2012.06.005

126. Rosa AR, Magalhães PV, Czepielewski L, Sulzbach MV, Goi PD, Vieta E, Gama CS, Kapczinski F (2014) Clinical staging in bipolar disorder: focus on cognition and functioning. Journal of Clinical Psychiatry. doi:10.4088/JCP.13m08625 
Table 1. Risk factors for the onset and development of bipolar disorder.

\begin{tabular}{|l|}
\hline First-degree relatives of patients with BD \\
Clinical manifestations \\
Subsyndromal bipolar spectrum symptoms \\
Depressive symptoms \\
Frequent comorbid disorders (anxiety, \\
ADHD) \\
Change in sleep \\
\hline Temperamental traits \\
\hline Substance use \\
Misuse and dependence \\
Antidepressant use \\
\hline Environmental factors \\
Abuse and maltreatment
\end{tabular}

Most of the staging models are based on additive risk factors that include genetics, clinical phenotypes, personality traits, substance abuse, and environmental factors. 
Table 2. Staging models developed for bipolar disorder.

\begin{tabular}{|c|c|c|}
\hline \multirow[t]{5}{*}{$\begin{array}{l}\text { Correll et al. 2007, } \\
2014[92,110]\end{array}$} & \multicolumn{2}{|l|}{$\begin{array}{l}\text { Bipolar Prodrome Symptom Scale } \\
\text { Prospective }\end{array}$} \\
\hline & Early prodromal stages & Subclinical, attenuated non-specific manic symptoms \\
\hline & Late prodromal stage & BD-NOS \\
\hline & A subsyndromal stage & Cyclothymia and hypomania \\
\hline & Syndromal stage & $\mathrm{BD}-\mathrm{I} / \mathrm{II}$ \\
\hline \multirow[t]{4}{*}{$\begin{array}{l}\text { Bechdolf et al. 2010, } \\
2014[111,112]\end{array}$} & Bipolar at Risk (BAR) & $\begin{array}{l}\text { Aged between } 15-25 \text { years } \\
\text { Fulfil criteria of at least one of three groups within the last } 12 \text { months } \\
\text { Exclusion criteria: history of manic episode } \geq 4 \text { days /psychosis } \geq 7 \text { days; past } \\
\text { treatment with an antipsychotic } \geq 3 \text { weeks or a mood stabiliser } \geq 6 \text { weeks; IQ } \\
\text { below the normal range; organic brain disorder. }\end{array}$ \\
\hline & Group 1 & $\begin{array}{l}\text { Sub-threshold manic symptoms: } \\
\text { (criteria for a manic episode } \geq 2 \text { consecutive days but }<4 \text { days) }\end{array}$ \\
\hline & Group 2 & $\begin{array}{l}\text { Depression plus cyclothymic features } \\
\text { (sub-threshold manic symptoms not meeting group } 1 \text { criteria) }\end{array}$ \\
\hline & Group 3 & $\begin{array}{l}\text { Depression plus genetic risk } \\
\text { (first degree relative with BD) }\end{array}$ \\
\hline \multirow[t]{5}{*}{$\begin{array}{l}\text { Leopold et al. 2012, } \\
2014[114,113]\end{array}$} & $\begin{array}{l}\text { The Early Phase Inventory for Bipolar } \\
\text { Disorders (EPIbipolar) }\end{array}$ & $\begin{array}{l}\text { Primary risk factors }(1,2) \text { and secondary risk factors (3-7) } \\
\text { (1) Family history of BD } \\
\text { (2) Subthreshold affective symptoms } \\
\text { increasing cyclothymia dynamic } \\
\text { (hypo)manic prodrome } \\
\text { (3) Changes in sleep and circadian rhythm } \\
\text { (4) Substance use } \\
\text { (5) ADHD symptoms or diagnosis } \\
\text { (6) Impairment of psychosocial functioning } \\
\text { (7) Symptoms of affective disorder other than BD or fearfulness/anxiety }\end{array}$ \\
\hline & No risk at present & \\
\hline & Risk status & $\begin{array}{l}\text { Specific changes in sleep and circadian rhythm and at least one of the other } \\
\text { secondary risk factors }\end{array}$ \\
\hline & High risk status & One primary and at least one secondary risk factor \\
\hline & Ultra-high risk status & More than one primary risk factor \\
\hline \multirow[t]{4}{*}{$\begin{array}{l}\text { McNamara et al. } 2010 \\
{[105]}\end{array}$} & & \\
\hline & Stage I & $\begin{array}{l}\text { Putative risk factors without prodromal symptoms } \\
\text { First-degree relative } \\
\text { Physical/sexual abuse } \\
\text { Psychosocial stress } \\
\text { Substance use/abuse } \\
\text { Stimulant; medications } \\
\text { N-3 fatty acid deficiency }\end{array}$ \\
\hline & Stage II & $\begin{array}{l}\text { Prodromal clinical features: } \\
\text { ADHD; unipolar depression; hypomania; anger/irritability; anxiety }\end{array}$ \\
\hline & Stage III & Onset of an episode of (hypo)mania \\
\hline \multicolumn{3}{|l|}{ Berk et al. 2014 [116] } \\
\hline & Stage 0 & Increased risk of BD; no specific current symptoms \\
\hline & Stage 1a & Mild or non-specific symptoms of mood disorder \\
\hline & Stage $1 b$ & $\begin{array}{l}\text { Ultra-high-risk: moderate but subthreshold symptoms, with neurocognitive } \\
\text { changes and functional decline to caseness }\end{array}$ \\
\hline & Stage 2 & First episode of threshold mood disorder \\
\hline & Stage $3 a$ & Recurrence of sub-threshold mood symptoms \\
\hline & Stage $3 \mathrm{c}$ & Multiple relapses \\
\hline & Stage 4 & $\begin{array}{l}\text { Severe, persistent illness as judged on symptoms, neurocognition and disability } \\
\text { criteria }\end{array}$ \\
\hline
\end{tabular}


Kapczinski et al.

2009; Brietzke et al.

2012 [6,29]

\begin{tabular}{ll|}
\hline Latent stage & $\begin{array}{l}\text { Individuals at an ultra-high-risk for developing BD present mood and anxiety } \\
\text { symptoms and increased risk (e.g., positive family history) }\end{array}$ \\
\hline Stage I & $\begin{array}{l}\text { Patients who have a diagnosis of BD and return to a baseline level of functioning } \\
\text { when the episodes resolve (without cognitive impairment) }\end{array}$ \\
\hline Stage II & $\begin{array}{l}\text { Mild functional impairment confined to co-morbidities (rapid cycling or current } \\
\text { axis I or II comorbidities, transient cognitive impairment) }\end{array}$ \\
\hline Stage III & $\begin{array}{l}\text { Severe impairment in cognition and global functioning (unable to work or very } \\
\text { impaired performance) }\end{array}$ \\
\hline Stage IV & Patients are unable to live autonomously due to BD morbidity \\
\hline
\end{tabular}



Table 3. Evaluation of the internal and external validity of staging models developed for bipolar disorder.

\begin{tabular}{|c|c|c|c|c|c|c|}
\hline & Methods & Population & Scales & Diagnosis/Classification & Internal validity & Predictive value \\
\hline $\begin{array}{l}\text { Correll et al. } \\
2014 \text { [110] }\end{array}$ & \begin{tabular}{|l} 
Cross- \\
sectional \\
study
\end{tabular} & $\begin{array}{l}\mathrm{N}=250 \\
12-23 \text { years } \\
\text { old } \\
\text { US }\end{array}$ & BPSS-P & $\begin{array}{l}\text { All mood spectrum disorders } \\
\mathrm{n}=129(52 \%) \\
\text { Depression spectrum } \\
\text { disorders } \mathrm{n}=77 \\
\text { Mood disorders NOS } \mathrm{n}=14 \\
\text { BD-NOS } \mathrm{n}=14 \\
\text { BD-I/BD-II/ Cyclothymia } \\
\mathrm{n}=11\end{array}$ & $\begin{array}{l}\text { For General } \\
\text { symptoms } \\
\alpha=0.74 \\
\text { ICC }=0.939 \\
\text { Manic symptoms } \\
\alpha=0.87 \\
\text { ICC }=0.934 \\
\text { Depressive } \\
\text { symptoms } \\
\alpha=0.89 \\
\text { ICC }=0.985\end{array}$ & No evaluation \\
\hline $\begin{array}{l}\text { Leopold et al. } \\
2014 \text { [114] }\end{array}$ & $\begin{array}{l}\text { Cross- } \\
\text { sectional } \\
\text { study }\end{array}$ & $\begin{array}{l}\mathrm{N}=180 \\
12-40 \text { years } \\
\text { old } \\
\text { Germany }\end{array}$ & $\begin{array}{l}\text { EPIbipolar; } \\
\text { BPSS-P }\end{array}$ & At risk $n=29(16 \%)$ & No evaluation & No evaluation \\
\hline $\begin{array}{l}\text { Bechdolf et } \\
\text { al. 2014[112] }\end{array}$ & $\begin{array}{l}\text { Prospective } \\
\text { study follow- } \\
\text { up } 12 \text { months }\end{array}$ & $\begin{array}{l}\mathrm{N}=559 \\
15-24 \text { years } \\
\text { old } \\
\text { Australia }\end{array}$ & $\begin{array}{l}\text { Comprehensive } \\
\text { Assessment of At- } \\
\text { Risk Mental } \\
\text { States }\end{array}$ & $\begin{array}{l}\text { At risk } n=35(6 \%) \\
\text { Group } 1 \mathrm{n}=10 \\
\text { Group } 2 \mathrm{n}=20 \\
\text { Group } 3 \mathrm{n}=3 \\
\text { Group } 1+2 \mathrm{n}=2\end{array}$ & $\begin{array}{l}\text { Classification } \\
\text { BAR/non-BAR } \\
\mathrm{k}=0.83\end{array}$ & $\begin{array}{l}\text { Conversion rate } \\
14.3 \% \\
\text { Group } 1 n=3 \\
\text { Group } 2 n=2 \\
\text { Group } 3 n=0\end{array}$ \\
\hline
\end{tabular}


BPSS-P= Bipolar Prodrome Symptom Interview and Scale-Prospective; ICC= intra-class correlation; $\alpha=$ Cronbach's alpha; $\mathrm{k}=$ Cohen's Kappa EPIbipolar= Early Phase Inventory for bipolar disorder 
Figure 1. Developmental course of bipolar disorder.

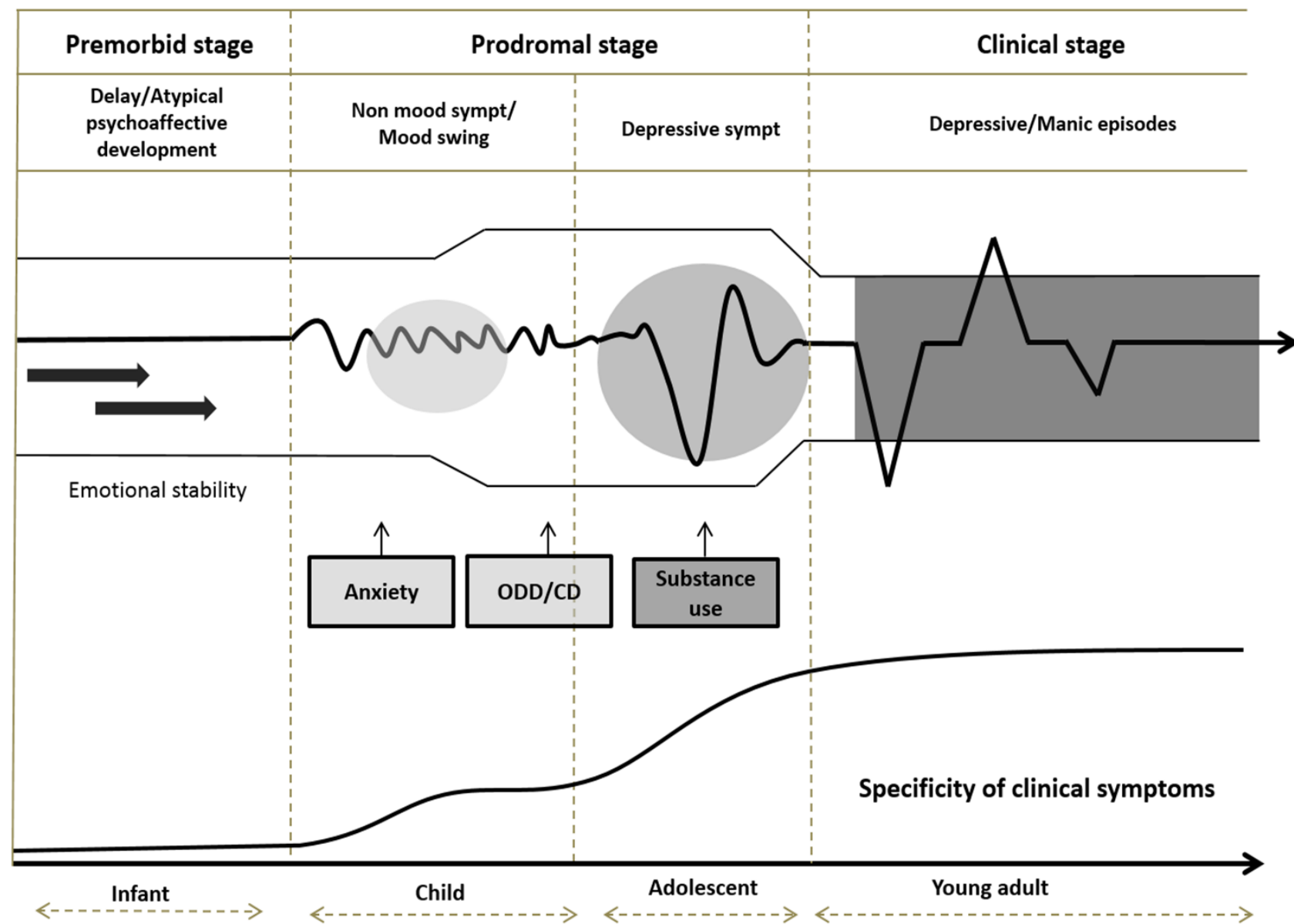

Sympt=symptoms; The high rate of comorbid disorders during childhood, as well as the on-going development of emotion regulation skills partly explained the low level of specificity of mood symptoms at this age. In contrast, the presentation of mood disorders in adolescents is more similar to that described in adults 

